Int. J. Dev. Biol. 55: 99-102 (2011)

doi: $10.1387 / \mathrm{ijdb} .103138 \mathrm{dr}$

\title{
Tryptase and chymase are angiogenic in vivo in the chorioallantoic membrane assay
}

\author{
DOMENICO RIBATTI*,1, GIROLAMO RANIERI ${ }^{2}$, BEATRICE NICO ${ }^{1}$, \\ VINCENZO BENAGIANO ${ }^{1}$ and ENRICO CRIVELLATO ${ }^{3}$
}

\begin{abstract}
${ }^{1}$ Department of Human Anatomy and Histology, University of Bari Medical School, Bari, ${ }^{2}$ Department of Critical Area and Surgery, National Cancer Institute Giovanni Paolo II, Bari and ${ }^{3}$ Department of Medical and Morphological Research, Section of Anatomy, University of Udine Medical School, Udine, Italy
\end{abstract}

\begin{abstract}
Human mast cells (MCs) are divided in two types depending on the expression of tryptase and chymase in their granules. Literature data indicate that both tryptase and chymase are angiogenic, but there is currently no evidence of their direct angiogenic activity in vivo. In this study, we have investigated the capacity of tryptase and chymase to promote vasoproliferation in chick embryo chorioallantoic membrane (CAM), a well established in vivo assay to study angiogenesis and anti-angiogenesis. The results showed that both tryptase and chymase stimulate angiogenesis and that the response is similar to that obtained with vascular endothelial growth factor (VEGF), a well-known angiogenic cytokine, and confirm the angiogenic activity of these two proteases stored in MC granules.
\end{abstract}

KEY WORDS: angiogenesis, chorioallantoic membrane, chymase, mast cells, tryptase

Human mast cells (MCs) are conventionally divided in two types depending on the expression of different proteases in their granules (Irani et al., 1986). MCs that contain tryptase only, are designed as $\mathrm{MC}_{\mathrm{T}}$ of "immune associated" MCs. They are predominantly located in the respiratory and intestinal mucosa, where they co-localize around T lymphocytes. MCs that contain both tryptase and chymase, along with other proteases such as carboxypeptidase $A$ and cathepsin $\mathrm{G}$, are referred as $\mathrm{MC}_{\mathrm{TC}}$. They are predominantly found in the connective tissue areas, such as skin, hypodermis and intestine, breast parenchyma, myocardium, lymph node, conjunctiva, and synovium. A third type of MC, called $\mathrm{MCc}$ has been identified, which express chymase without tryptase and resides mainly in the submucosa and mucosa of the stomach, small intestinal submucosa, and colonic mucosa (Irani and Schwartz, 1994).

Tryptase and chymase are involved in angiogenesis after their release from activated $\mathrm{MC}$ granules. Their proteolytic activities degrade extracellular matrix components or release matrix-associated growth factors (Taipale et al., 1995), and they also act indirectly by activating latent matrix metalloproteinases (Gruber et al., 1989) and plasminogen activators, both key enzymes of proteolytic systems that contribute to the degradation of extracellular matrix components (Stack and Johnson, 1994). Extracellular matrix degradation is a critical step in the early stages of angio- genesis as well as during invasion and metastasis of tumor cells.

Blair et al. (1997), have demonstrated the angiogenic potential of tryptase in vitro and its important role in neovascularization. Tryptase added to microvascular endothelial cells cultured on Matrigel caused a pronounced increase in capillary growth, and this was suppressed by specific tryptase inhibitors. Moreover, tryptase directly induced endothelial cell proliferation in a dosedependent fashion. Human chymase can induce angiogenesis by converting angiotensin I to angiotensin II, as was demonstrated in a hamster sponge model (Muramatsu et al., 2000).

The chick embryo chorioallantoic membrane (CAM) is an extraembryonic membrane which serves as a gas exchange surface and its function is supported by a dense capillary network. Because of its extensive vascularization and easy accessibility, the CAM has been broadly used to study the morphofunctional aspects of the angiogenesis process in vivo and to investigate the efficacy and mechanisms of action of pro-angiogenic and antiangiogenic natural and synthetic molecules (Ribatti, 2008).

In this study, we have investigated the capacity of exogenous tryptase and chymase to promote vasoproliferation in the CAM assay.

Abbreviations used in this paper: CAM, chorioallantoic membrane; MC, mast cell.

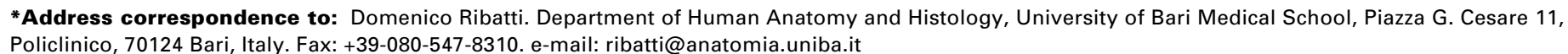




\section{Results and Discussion}

At day 12 of incubation, vehicle alone did not induce any angiogenic response (mean number of vessels $=8 \pm 2$ ) (not shown) (Fig. 1), whereas a significant angiogenic response was induced by vascular endothelial growth factor (VEGF) in form of numerous allantoic neovessels developing radially towards the implant in a 'spoked-wheel' pattern (mean number of vessels = 25 \pm 4 ) (not shown) (Fig. 1). When human recombinant tryptase or chymase were tested at a concentration of $200 \mathrm{ng}$, they induced a strong angiogenic response (mean number of vessels $=24 \pm 4$ for tryptase and, respectively, $22 \pm 3$ for chymase (Figs. 1 and 2 $A, B)$. Lower doses did not have an angiogenic effect, while when both tryptase and chymase were tested at 300 ng/embryo they induce a comparable angiogenic effect.

Histological examination of the sponges treated with tryptase and chymase showed numerous blood vessels inside the sponge trabeculae (Fig. 2C). Moreover, at the boundary between the sponge and the CAM mesenchyme, numerous host capillaries were recognizable, piercing the sponge at some points. In contrast, no blood vessels were recognizable among the sponge trabeculae in sponges treated with PBS (Fig. 2D).

In this study, for the first time we have demonstrated an angiogenic activity of human recombinant tryptase and chymase in vivo in the CAM assay, comparable to the angiogenic response induced by a well-known angiogenic cytokine, namely VEGF.

There is increasing evidence to support the view that angiogenesis and inflammation are mutually dependent (Ribatti and Crivellato, 2009a). During inflammatory reactions, immune cells, including macrophages, neutrophils, lymphocytes and mast cells, synthesize and secrete pro-angiogenic factors that promote neovascularization. On the other hand, the newly formed vascular supply contributes to the perpetuation of inflammation by promoting the migration of inflammatory cells to the site of inflammation. Tumor cells are surrounded by an infiltrate of inflammatory cells, which communicate via a complex network of intercellular signaling pathways, mediated by surface adhesion molecules, cytokines and their receptors. Accordingly, immune cells cooperate and synergize with stromal cells as well as malignant cells in stimulat-

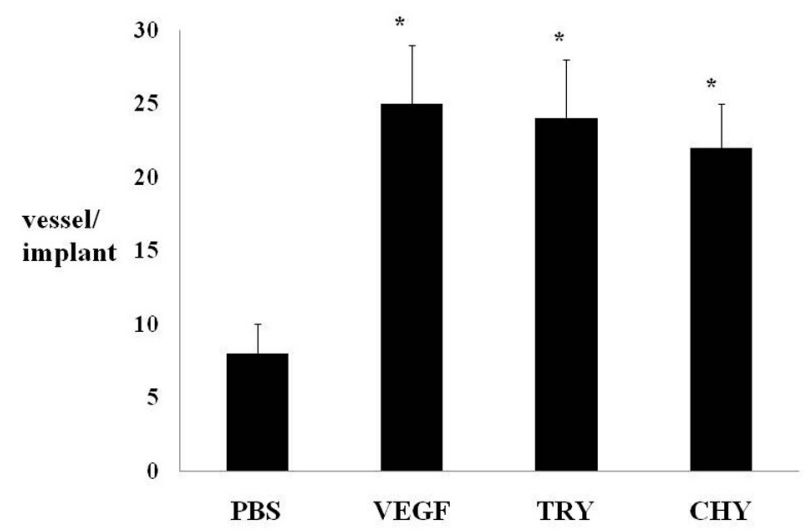

Fig 1. Tryptase (TRY) and chymase (CHY) trigger an angiogenic response in the chorioallantoic membrane (CAM) assay. This response is comparable to that induced by vascular endothelial growth factor (VEGF). ${ }^{*} p<0.001$ vs PBS.
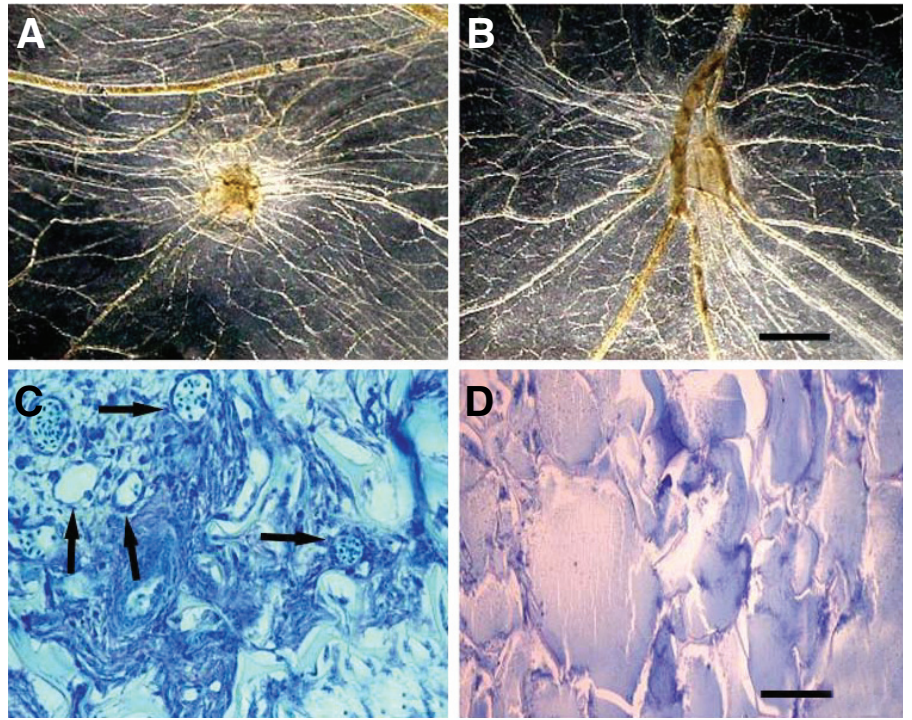

Fig. 2. Tryptase and chymase are angiogenic in vivo in the CAM assay. In (A,B) macroscopic pictures of CAMs at day 12 of incubation, treated with tryptase $(\mathbf{A})$ and chymase $(\mathbf{B})$ respectively. Note the presence of numerous blood vessels converging toward the implant. (C,D) Histological pictures of CAMs treated with tryptase and the vehicle alone, respectively. Note in (C) numerous microvessels inside the sponge (arrows), while in the control specimen (D), no blood vessels are recognizable. Scale bars: (A,B) $25 \mu \mathrm{m}$; (C,D) $100 \mu \mathrm{m}$.

ing endothelial cell proliferation and blood vessel formation (Ribatti et al., 2006b).

For almost two decades MCs, strategically located in proximity of blood vessels, have been associated with tumor angiogenesis. A positive correlation between MC density and microvascular density has been established in esophageal squamous cell carcinoma (Tomita et al., 2001), primary colorectal cancer (Acikalin et al., 2005; Gulubova and Vlaykova, 2009), hepatocellular carcinoma (Peng et al., 2005); pancreatic adenocarcinoma (Esposito et al., 2004), renal cell carcinoma (Tuna et al., 2006), non-small cell lung cancer (Imada et al., 2000; Ibaraki et al., 2005).

Tryptase and chymase are involved in angiogenesis after their release from activated mast cells granules (Ribatti et al., 2009 b). Tryptase-positive mast cells increase in number and vascularization increases in a linear fashion in solid tumors, such as human malignant melanoma (Ribatti et al., 2003 a, b), endometrial carcinoma (Benítez-Bribiesca et al. 2001, Ribatti et al. 2005), breast cancer (Ribatti et al., 2007a; Ranieri et al., 2009), uterine leiomyomas (Ribatti et al., 2007b), colorectal cancer (Gulubova and Vlaykova, 2009).

As concerns hematological tumors, in benign lymphadenopathies and B cell non-Hodgkin's lymphomas, angiogenesis correlates with tryptase-positive mast cell counts, and both increase in step with the increase with malignancy grades (Ribatti et al., 2000). In the bone marrow of patients with inactive and active multiple myeloma as well as those with monoclonal gammopathies of undetermined significance, angiogenesis highly correlates with tryptase-positive mast cells (Ribatti et al., 1999). A similar pattern of correlation between bone marrow microvessel count, total and tryptase-positive mast cell density and tumor progression has been found in patients with myelodysplastic syndrome (Ribatti et 
al., 2002) and B cell chronic lymphocytic leukemia (Ribatti et al., 2003 c). In B cell chronic lymphocytic leukemia, the density of tryptase-positive mast cell in the bone marrow has been shown to predict the outcome of the disease (Molica et al., 2003).

Other authors have parallely investigated the presence of $\mathrm{MC}_{\mathrm{T}}, \mathrm{MC}_{\mathrm{C}}$ and $\mathrm{MC}_{\mathrm{TC}}$ and have demonstrated a correlation between their number and microvascular density in uterine cervix cancer (Cabanillas-Saez et al., 2002; Wilk et al., 2010), gastric cancer (Ribatti et al., 2010) and in non small cell lung cancer (Carlini et al., 2010).

The complex interplay between MCs and angiogenesis have led to consider the therapeutic use of angiogenesis inhibitors, which specifically target the angiogenic activity of tryptase and chymase. In this context, tryptase inhibitors such as gabexate mesilate and nafamostat mesilate (Erba et al., 2001; Mori et al., 2003; Uchima et al., 2007) might be proposed as antiangiogenic agents in combination with chemotherapy in the treatment of cancer.

\section{Materials and Methods}

Fertilized White Leghorn chicken eggs (20 per group) were incubated at $37^{\circ} \mathrm{C}$ at constant humidity. On day 3 , a square window was opened in the shell, and 2 to $3 \mathrm{ml}$ of albumen were removed to allow detachment of the developing CAM from the shell. The window was sealed with a glass, and the eggs were returned to the incubator. On day 8 , eggs were treated with $1 \mathrm{~mm}^{3}$ sterilized gelatin sponges (Gelfoam Upjohn Company, Kalamazoo, MI, USA) placed on top of the growing CAM, as previously described (Ribatti et al., 2006a) and loaded with: $2 \mu$ l of PBS as negative control; $2 \mu \mathrm{l}$ of PBS containing $50 \mathrm{ng}$ of recombinant VEGF-A alone as positive control ( $R$ \& D Systems, Abington, UK) or 2 of PBS containing human recombinant tryptase or chymase administered at a concentration of 50, 100, 200, $300 \mathrm{ng}$ (Sigma-Aldrich, St Louis, MO, USA). CAMs were examined daily until day 12 and photographed in ovo with a stereomicroscope equipped with a camera and image analyzer system (Olympus Italia, Rozzano, Italy). At day 12 the angiogenic response was evaluated by the image analyzer system as the number of vessels centering the sponges within the focal plane of the CAM. Means \pm 1 Standard Deviation (SD) were evaluated for all the parameters and the statistical significance of the differences between the counts was determined by Student's $t$-test for unpaired data.

CAMs were also processed for light microscopy. Briefly, the embryos and their membranes were fixed in ovo in Bouin's fluid. The sponges and the underlying and immediately adjacent CAM portions were removed and processed for embedding in paraffin. Eight $\mu \mathrm{m}$ serial sections were cut along a plane parallel to the CAM surface, stained with $0.5 \%$ aqueous toluidine blue (Merck, Darmtadt, Germany) and observed under a light microscope.

\section{Acknowledgements}

Supported in part by MIUR (PRIN 2007), Rome, and Fondazione Cassa di Risparmio di Puglia, Bari, Italy.

\section{References}

ACIKALIN MF, ONER U, TOPCU, I., YASAR, B., KIPER, H. and COLAK, E. (2005). Tumour angiogenesis and mast cell density in the prognostic assessment of colorectal carcinomas. Dig Liver Dis 37: 162-169.

BLAIR, R.J., MENG, H., MARCHESE, M.J., REN, S., SCHWARTZ, L.B., TONNESEN, M.G. and GRUBER, B.L. (1997). Human mast cells stimulate vascular tube formation. Tryptase is a novel, potent angiogenic factor. J Clin Invest99: 2691-2700.

BENÍTEZ-BRIBIESCA, L., WONG, A., UTRERA, D. and CASTELLANOS, E.
(2001). The role of mast cell tryptase in neoangiogenesis of premalignant and malignant lesions of the uterine cervix. $J$ Histochem Cytochem 49: 1061-1062.

CABANILLAS-SAEZ, A., SCHALFER, J.A., NICOVANI, S.M. and RUDOLPH, M.I. (2002). Characterization of mast cells according to their content of tryptase and chymase in normal and neoplastic human uterine cervix. Int $J$ Gynecol Cancer 12: 92-98.

CARLINI, M.J., DALURZO, M.C., LASTIRI, J.M., SMITH, D.E., VASALLO, B.C., PURICELLI, L.I. and LAURÍA DE CIDRE, L.S. (2010). Mast cell phenotypes and microvessel in non-small cell lung cancer and its prognostic significance. Human Pathol 41: 697-705.

ERBA, F., FIORUCCI, L., PASCARELLA, S., MNEGATTI, E., ASCENZI, P. and ASCOLI, F. (2001). Slective inhibition of human mast cell tryptase by gabexate mesylate, an antiproteinase drug. Biochem Pharmacol 61: 271-276.

ESPOSITO, I., MENUCAGLI, M., FUNEL, N., BERMANN, F., BOGGI, U., MOSCA, F., BEVILACQUA, G. and CAMPANI, D. (2004). Inflammatory cells contribute to the generation of an angiogenic phenotype in pancreatic ductal adenocarcinoma. J Clin Pathol 57: 630-636.

GULOBOVA, M. and VLAYKOVA, T. (2009). Prognostic significance of mast cell number and microvascular density for the survival of patients with primary colorectal cancer. J Gastroenterol Hepatol 24: 1265-1275.

GRUBER, B.L., MARCHESE, M.J., SUZUKI, K., SCHWARTZ, L.B., OKADA, Y., NAGASE, H. and RAMAMURTHY, N.S. (1989). Synovial procollagenase activation by human mast cell tryptase dependence upon matrix metalloproteinase 3 activation. $J$ Clin Invest 84: 1657-1662.

GULUBOVA, M. and VLAYKOVA, T. (2009). Prognostic significance of mast cell number and microvascular density for the survival of patients with primary colorectal cancer. J Gastroenterol Hepatol 24: 1265-1275.

IBARAKI, T., MURAMATSU, M., TAKAI, S., JIN, D., MARUYAMA, H., ORINO, T., KATSUMATA, T. and MIYAZAKI, M. (2005). The relationship of tryptase- and chymase-positive mast cells to angiogenesis in stage I non-small cell lung cancer. Eur J Cardiothorac Surg 28: 617-621.

IMADA, D., SHIJUBO, N., KOJIMA, H. and ABE, S. (2000). Mast cells correlate with angiogenesis and poor outcome in stage I lung adenocarcinoma. Eur Respir $J$ 15: 1087-1093.

IRANI, A.M., SCHECHTER, N.M., CRAING, S.S., DE BLOIS, G. and SCHWARTZ, L.B. (1986). Two types of human mast cells that have distinct neutral protease composition. Proc Natl Acad Sci USA 63: 4464-4468.

IRANI, A.M. and SCHWARTZ, L.B. (1994). Human mast cells heterogeneity. Allergy Proc 15: 303-308.

MOLICA, S., VACCA, A., CRIVELLATO, E., CUNEO, A. and RIBATTI, D. (2003). Tryptase-positive mast cells predict clinical outcome of patients with early B-cell chronic lymphocytic leukemia. Eur J Haematol 71: 137-139.

MORI, S., ITOH, Y., SHINOHATA, R., SENEDO, T., OISHI, R. and NISHIBORI, M. (2003). Nafamostat mesilate is an extremely potent inhibitor of human tryptase. J Pharmacol Sci 92: 420-423.

MURAMATSU, M., KATADA, J., HATTORI, M., HAYASHI, I. and MAJIMA, M. (2000). Chymase mediates mast cell-induced angiogenesis in hamster sponge granulomas. Eur J Paharmacol 402: 181-191.

PENG, S.H., DENG, H., YANG, J.F., XIE, P.P., LI, C., LI H. and FENG, D.Y. (2005) Significance and relationship between infiltrating inflammatory cells and tumor angiogenesis in hepatocellular carcinoma tissues. World J Gastroenterol 11: 6521-6523.

RANIERI, G., AMMENDOLA, M., PATRUNO, R., CELANO, G., ZITO, F.A., MONTEMURRO, S., RELLA, A., DI LECCE, V., GADALETA, C.D., DE SARRO, G.B. and RIBATTI, D. (2009). Tryptase-positive mast cells correlate with angiogenesis in early breast cancer patients. Int $J$ Oncol 35: 115-120.

RIBATTI, D., VACCA, A., NICO, B., QUONDAMATTEO, F., RIA, R., MINISCHETTI, M., MARZULLO, A., HERKEN, R., RONCALI, L. and DAMMACCO, F. (1999). Bone marrow angiogenesis and mast cell density increase simultaneously with progression of human multiple myeloma. $\mathrm{Br} J$ Cancer 79: 451-455.

RIBATTI, D., VACCA, A., MARZULLO, A., NICO, B., RIA, R., RONCALI, L. and DAMMACCO, F. (2000). Angiogenesis and mast cell density with tryptase activity increase simultaneously with pathological progression in B-cell nonHodgkin's lymphomas. Int J Cancer 85: 171-175.

RIBATTI, D., CRIVELLATO, E., CANDUSSIO, L., NICO, B., VACCA, A., RONCALI, L. and DAMMACCO, F. (2001). Mast cells granules and their secretory granules 
are angiogenic in the chick embryo chorioallantoic membrane. Clin Exp Allergy 31: $602-608$.

RiBATTI, D., POlimeno, G., VACCA, A., MARZUllo, A., CRIVELlAto, E., NICO, B., LUCARELLI, G. and DAMMACCO, F. (2002) Correlation of bone marrow angiogenesis and mast cells with tryptase activity in myelodysplastic syndromes. Leukemia 16: 1680-1684.

RIBATTI, D., VACCA, A., RIA, R., MARZULLO, A., NICO, B., FILOTICO, R., RONCALI, L. and DAMMACCO, F. (2003 a). Neovascularisation, expression of fibroblast growth factor-2, and mast cells with tryptase activity increase simultaneously with pathological progression in human malignant melanoma. Eur $J$ Cancer 39: 666-674.

RIBATTI, D., ENNAS, M.G., VACCA, A., FERRELI, F., NICO, B., ORRU, S. and SIRIGU, P. (2003 b) Tumor vascularity and tryptase-positive mast cells correlate with a poor prognosis in melanoma. Eur J Clin Invest 33: 420-425.

RIBATTI, D., MOLICA, S., VACCA, A., NICO, B., CRIVELLATO, E., ROCCARO, A.M. and DAMMACCO, F. (2003 c) Tryptase-positive mast cells correlate positively with bone marrow angiogenesis in B-cell chronic lymphocytic leukemia. Leukemia 17: 1428-1430.

RIBATTI, D., FINATO, N., CRIVELlATO, E., MARZULLO, A., MANGIERI, D., NICO, B., VACCA, A. and BELTRAMI, C.A. (2005). Neovascularization and mast cells with tryptase activity increase simultaneously with pathologic progression in human endometrial cancer. Am J Obstet Gynecol 193: 1961-1965.

RIBATTI, D., NICO, B., VACCA, A. and PRESTA, M (2006 a). The gelatin spongechorioallantoic membrane assay. Nature Prot 1: 85-91.

RIBATTI, D., NICO, B. and VACCA, A. (2006 b).'Importance of the bone marrow microenvironment in inducing the angiogenic response in multiple myeloma. Oncogene 25: 4257-4266.

RIBATTI, D., FINATO, N., CRIVELLATO, E., GUIDOLIN, D., LONGO, V., MANGIERI, D., NICO, B., VACCA, A. and BELTRAMI, C.A. (2007 a). Angiogenesis and mast cells in human breast cancer sentinel lymph nodes with and without micrometastases. Histopathology 51: 837-842.

RIBATTI, D., BELLONI, A.S., NICO, B., SALÀ, G., LONGO, V., MANGIERI, D. CRIVELLATO, E. and NUSSDORFER, G.G. (2007 b). Tryptase- and leptinpositive mast cells correlate with vascular density in uterine leiomyomas. Am J Obstet Gynecol 196: 470.e 1-7.

RIBATTI, D. (2008). Chick embryo chorioallantoic membrane as a useful tool to study angiogenesis. Int Rev Cell Mol Biol 270: 181-224.

RIBATTI, D. and CRIVELLATO, E. (2009 a). Immune cells and angiogenesis. J Cell Mol Med 13: 2822-2833.

RIBATTI, D. and CRIVELLATO, E. (2009 b). The controversial role of mast cells in tumor growth. Int Rev Cell Mol Biol 275: 89-131.

RIBATTI, D., GUIDOLIN, D., MARZULLO, A., NICO, B., ANNESE, T., BENAGIANO, V. and CRIVELLATO, E. (2010). Mast cells and angiogenesis in gastric carcinoma. Int J Exp Pathol 91: 350-356.

STACK, M.S. and JOHNSON, D.A. (1994). Human mast cell tryptase activates single-chain urinary-type plasminogen activator (pro-urokinase). J Biol Chem 269: 9416-9419.

TAIPALE, J., LOHI, J., SAARINEN, J., KOVANEN, K.T. and KESHI-OJA, J. (1995). Human mast cell chymase and leukocyte elastase release latent transforming growth factor beta-1 from the extracellular matrix of cultured human epithelial and endothelial cells. J Biol Chem 270: 4689-4696.

TUNA, B., YORUKOGLU, K., UNLU, M., MUNGAN, M.U., KIRZOLI, Z. (2006). Association of mast cells with microvessel density in renal cell carcinoma. Eur J Urol 50: 530-534.

UCHIMA, Y., SAWADA, T. and HIRIKAWA, K. (2007). Action of antiproteases on pancreatic cancer cells. J Pancreas 8 (4 Suppl): 479-487.

WILK, M., LISZKA, L., PALEN, P., GABRIEL, A. and LAUDANSKI, P. (2010). Intensity of angiogenesis and mast cell infiltration in cervical intraepithelial and invasive lesions-are they corrrelated? Pathol Res Pract 206: 217-222. 


\section{Further Related Reading, published previously in the Int. J. Dev. Biol.}

See our recent Special Issue Placenta edited by Joan S. Hunt and Kent L. Thornburg at: http://www.ijdb.ehu.es/web/contents.php?vol=54\&issue=2-3

The seminal work of Werner Risau in the study of the development of the vascular system Domenico Ribatti

Int. J. Dev. Biol. (2010) 54: 567-572

Vasculogenesis and angiogenesis in the mouse embryo studied using quail/mouse chimeras

Michel Pudliszewski and Luc Pardanaud

Int. J. Dev. Biol. (2005) 49: 355-361

Differentiation of the mouse embryoid bodies grafted on the chorioallantoic membrane of the chick embryo

S Gajovic and P Gruss

Int. J. Dev. Biol. (1998) 42: 225-228

The chick embryo chorioallantoic membrane as a model for in vivo research on angiogenesis

D Ribatti, A Vacca, L Roncali and F Dammacco

Int. J. Dev. Biol. (1996) 40: 1189-1197

Reorganization of blood vessels after their partial section in the chick embryo chorioallantoic membrane

D Ribatti

Int. J. Dev. Biol. (1994) 38: 117-120

5 yr ISI Impact Factor $(2008)=3.271$
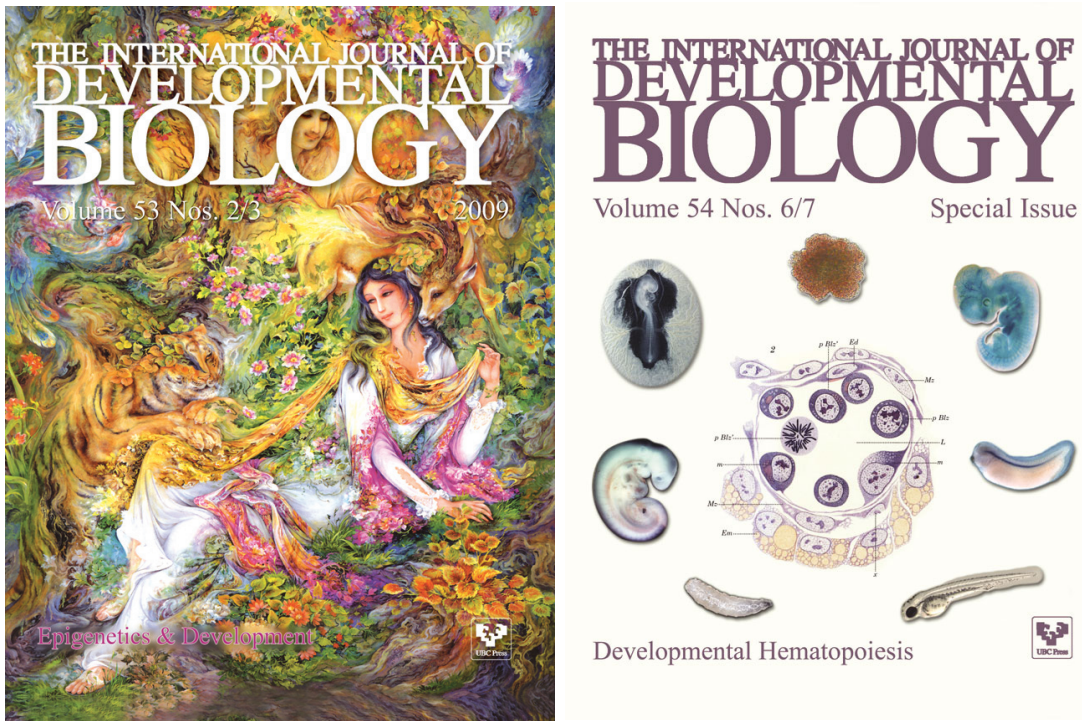

Volume 54 Nos. 6/7

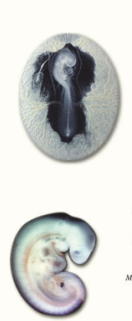

Special Issue
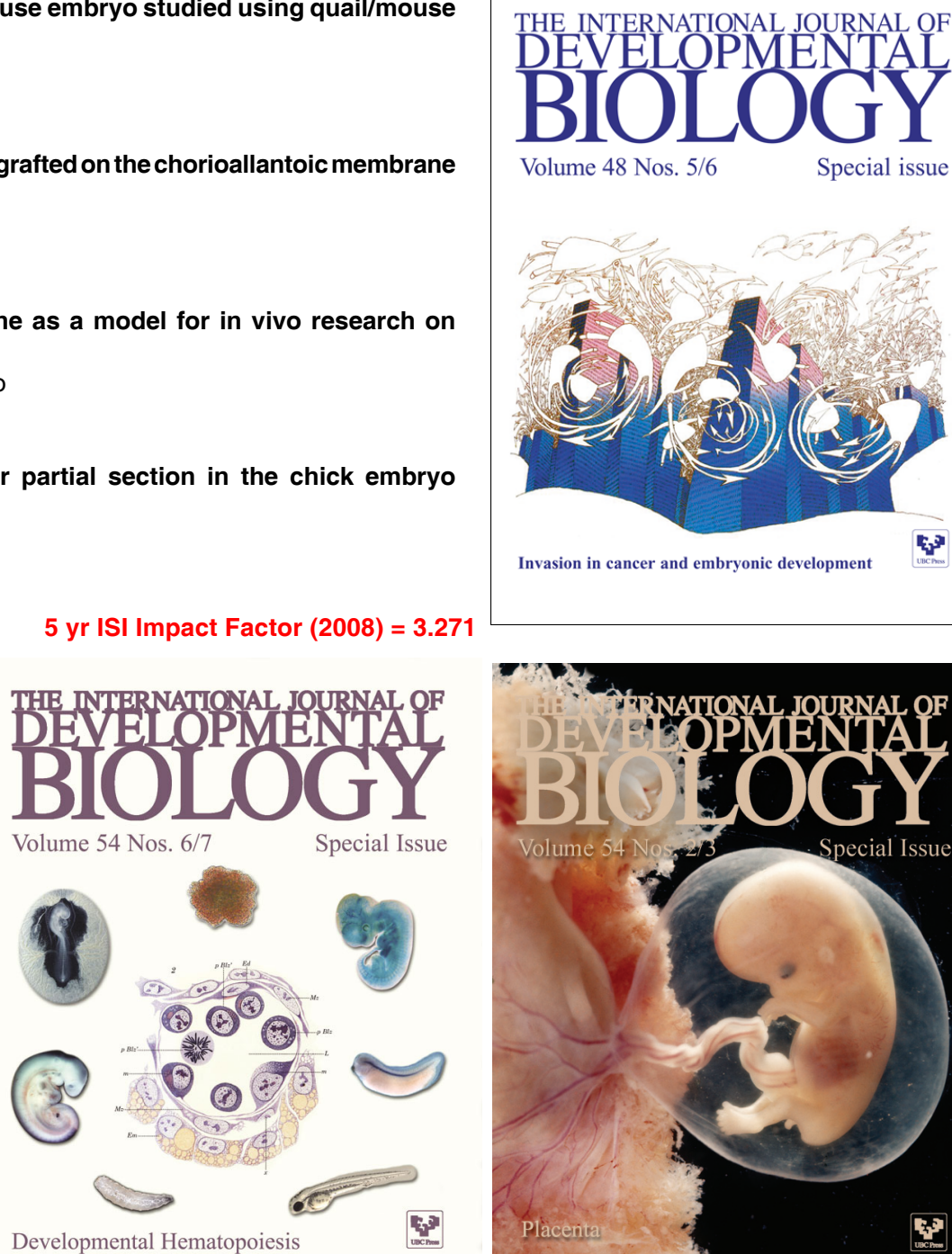

Volume 48 Nos. 5/6

Special issue

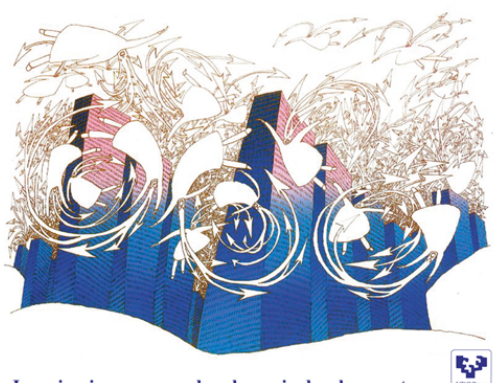

Invasion in cancer and embryonic development

E्रे

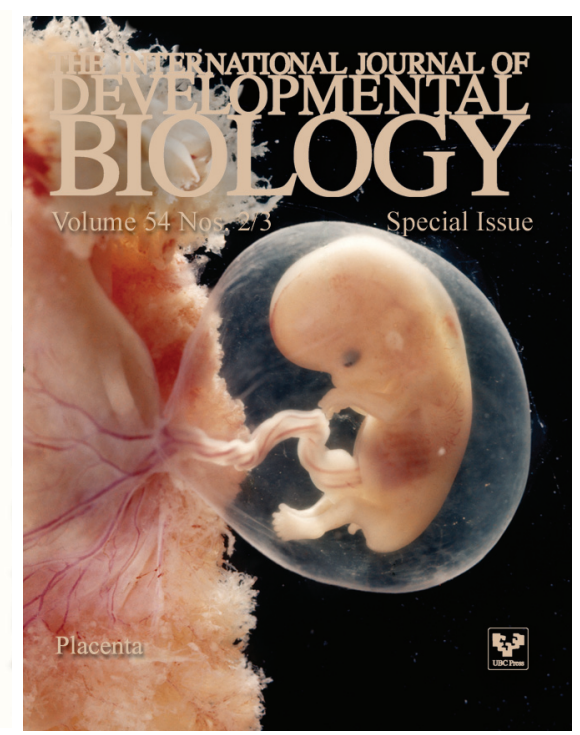

